Isaac Jordão de Souza ARAÚJO(a) Mariana Gallante RICARDO(b) Orisson Ponce GOMES(c) (1) Priscila Alves GIOVANI(d) Júlia PUPPIN-RONTANI(a) (1) Vanessa Arias PECORARI(e) (D) Elizabeth Ferreira MARTINEZ ${ }^{\text {(b) }}$ (i) Marcelo Henrique NAPIMOGA ${ }^{\text {(b) }}$ (b) Francisco Humberto NOCITI JUNIOR ${ }^{(f)}$ (1)

Regina Maria PUPPIN-RONTANI(d) (c) Paulo Noronha LISBOA-FILHO(c) (1) Kamila Rosamilia KANTOVITZ ${ }^{(b)}$ (D)

(a) Universidade Estadual de Campinas - Unicamp, Piracicaba Dental School, Department of Restorative Dentistry,

Piracicaba, SP, Brazil.

(b)Faculdade São Leopoldo Mandic, Dental Research Center, Campinas, SP, Brazil.

(c) Universidade Estadual Paulista Júlio Mesquita Filho - UNESP, School of Sciences, Department of Physics, Bauru, SP, Brazil.

(d) Universidade Estadual de Campinas - Unicamp, Piracicaba Dental School, Department of Pediatric Dentistry, Piracicaba, SP, Brazil.

(e) Universidade Paulista - UNIP, School of Dentistry, Department of Bioestatistics, São Paulo, São Paulo, Brazil.

(f) Universidade Estadual de Campinas - Unicamp, Piracicaba Dental School, Department of Prosthodontics and Periodontology, Piracicaba, SP, Brazil.

Declaration of Interests: The authors certify that they have no commercial or associative interest that represents a conflict of interest in connection with the manuscript.

Corresponding Author:

Kamila Rosamilia Kantovitz

E-mail:kamilark@yahoo.com.br;

kamila.kantovitz@sImandic.edu.br

https://doi.org/10.1590/1807-3107bor-2021.vol35.0062

Submitted: June 11,2020

Accepted for publication: November 11, 2020

Last revision: January 8, 2021

\section{Titanium dioxide nanotubes added to glass ionomer cements affect S. mutans viability and mechanisms of virulence}

Abstract: This in vitro study evaluated the impact of $\mathrm{TiO}_{2}$ nanotubes $\left(\mathrm{n}-\mathrm{TiO}_{2}\right)$ incorporated into glass ionomer cement (GIC) on Streptococcus mutans (S. mutans) characteristics at cellular and molecular levels. $\mathrm{n}-\mathrm{TiO}_{2}$, synthesized by the alkaline method ( $20 \mathrm{~nm}$ in size), was added to Ketac Molar EasyMix ${ }^{\circledR}$ at $0 \%, 3 \%, 5 \%$, and $7 \%$ by weight. S. mutans strains were cultured on GIC disks with addition or not of $\mathrm{n}-\mathrm{TiO}_{2}$ for 1,3 , and 7 days and the following parameters were assessed: inhibition halo $(\mathrm{mm})$ ( $n=3 /$ group); cell viability (live/dead) ( $n=5 /$ group); cell morphology (SEM) (n=3/group); and gene expression by real-time PCR (vicR, covR, $g t f B, g t f C$, and $g t f D)(\mathrm{n}=6 /$ group). The data were analyzed by the Kruskal-Wallis test, repeated-measures ANOVA or two-way ANOVA, and Tukey's and Dunn's post-hoc tests $(\alpha=0.05)$. The agar diffusion test showed a higher antibacterial property for $5 \% \mathrm{n}-\mathrm{TiO}_{2}$ compared with $3 \%$ and $7 \%(p<0.05)$ with no effect of time $(1,3$, and 7 days). The cell number was significantly affected by all $\mathrm{n}-\mathrm{TiO}_{2}$ groups, while viability was mostly affected by $3 \%$ and $5 \% \mathrm{n}-\mathrm{TiO}_{2}$, which also affected cell morphology and organization. Real-time PCR demonstrated that n- $\mathrm{TiO}_{2}$ reduced the expression of $\operatorname{cov} R$ when compared with GIC with no n- $\mathrm{TiO}_{2}$ $(\mathrm{p}<0.05)$, with no effect of time, except for $3 \% \mathrm{n}-\mathrm{TiO}_{2}$ on vicR expression. Within-group and between-group analyses revealed $n-\mathrm{TiO}_{2}$ did not affect mRNA levels of $g t f B, g t f C$, and $g t f D(p>0.05)$. Incorporation of $\mathrm{n}-\mathrm{TiO}_{2}$ at $3 \%$ and $5 \%$ potentially affected $S$. mutans viability and the expression of key genes for bacterial survival and growth, improving the anticariogenic properties of GIC.

Keywords: Nanotechnology; Glass Ionomer Cements; Titanium; Gene Expression.

\section{Introduction}

Glass ionomer cement (GIC) is a polyvalent restorative material based on an acid-base reaction between a powder (silicate, fluoride, or aluminum) and a liquid (polyacrylic, maleic, tartaric, or itaconic acids). ${ }^{1}$ The use of GIC in clinical dentistry is associated with its chemical bonding to the dental structure and to its anticariogenic activity as a result of ion release. ${ }^{2}$ By contrast, GICs are fragile in highly tensive regions because of their low cohesive strength, ${ }^{3}$ especially in multiple-surface cavities. ${ }^{4}$ Furthermore, the fluoride content released from GIC varies from 2 to $10 \mathrm{ppm}$ in the first 
2 days ${ }^{5,6}$ and this release dramatically decreases up to 14 days. $^{7}$ Thus, the use of GIC is frequently limited to atraumatic restorative treatment (ART), procedures in primary teeth, ${ }^{8}$ and non-carious cervical lesions. ${ }^{9,10}$

In order to improve the anticariogenic activity and mechanical properties of GICs, some studies have focused on the addition of bioactive particles to ionomer materials. ${ }^{11,12,13}$ Among several materials, titanium dioxide $\left(\mathrm{TiO}_{2}\right)$ has been incorporated into $\mathrm{GIC}^{14,15,16,17}$ due to its high biocompatibility and mechanical properties and also because of its potential antimicrobial activity. Recent studies have shown that GIC reinforced with nanostructured $\mathrm{TiO}_{2}$ exhibited improved mechanical properties, ${ }^{15}$ increased fluoride release ${ }^{14}$ and a higher antimicrobial potential compared with conventional GIC.16,17 However, the mechanisms associated with the antimicrobial effects of $\mathrm{TiO}_{2}$ nanotechnologies remain unclear. Furthermore, some authors support that size, shape, and crystallinity are determining factors for the final quality of titanium nanotubes $\left(\mathrm{n}-\mathrm{TiO}_{2}\right){ }^{18,19,20} \mathrm{It}$ has been suggested that the effect of nanoparticle incorporation into GIC is potentially related to the improvement of homogeneity and consistency of the material, which reduces microcracks and air void formation into the cement matrix. ${ }^{21}$ Therefore, the use of nanotechnology represents a remarkable advance in developing biologically active materials. ${ }^{22}$

Apart from that, antibacterial agents incorporated into restorative materials have suppressed bacterial growth, ${ }^{23,24,25}$ helping minimize the risk of recurrent caries and damage to the dental pulp. ${ }^{2}$ The incorporation of antibacterial agents possibly affects the structure and metabolism of bacteria by damaging important genes ${ }^{25}$ such as glucosyltransferases $(g t f B, g t f C$, and $g t f D)$, responsible for extracellular polysaccharide synthesis, and the two-component transduction systems (TCS), $\operatorname{cov} R$ and vicR, which are, respectively, inhibitory and excitatory response regulators for bacterial virulence that modulate the expression of gtfs genes. ${ }^{26,27}$

However, it is not known whether n- $\mathrm{TiO}_{2}$ addition to conventional GIC would affect cellular and molecular mechanisms involved in bacterial cariogenic potential. Therefore, the aim of this in vitro study was to assess the impact of different concentrations of $\mathrm{n}-\mathrm{TiO}_{2}$ incorporated into GIC on the biology of S. mutans cultures at the cellular and molecular levels. In the present investigation, the null hypothesis was that $\mathrm{n}-\mathrm{TiO}_{2}$ added to a conventional GIC would not affect S. mutans biology during the initial periods of biofilm formation, including cell viability, morphology, and gene expression.

\section{Methodology}

\section{Experimental design}

The current study assessed the incorporation of $\mathrm{TiO}_{2}$ nanotubes $\left(\mathrm{n}-\mathrm{TiO}_{2}\right)$ based on concentration levels (\% by weight) into a conventional high-viscosity GIC (Ketac Molar Easymix ${ }^{\mathrm{TM}}$ - 3M/ESPE, Maplewood, Minnesota, USA, batches \#585454, \#635287, \#610966, and \#588869) and the maturation time of the single-species biofilm formed on the material (1, 3 , and 7 days). GIC samples were assigned to four experimental groups according to the concentration of $\mathrm{n}-\mathrm{TiO}_{2}$ : GIC $=$ Control; $\mathrm{GIC}+3 \% \mathrm{n}-\mathrm{TiO}_{2} ; \mathrm{GIC}+5 \%$ $\mathrm{n}-\mathrm{TiO}_{2} ;$ and $\mathrm{GIC}+7 \% \mathrm{n}-\mathrm{TiO}_{2}$ following the previous studies of our group. ${ }^{14,15} \mathrm{~S}$. mutans strains were cultured on GIC disks and the following parameters were assessed: inhibition halo $(\mathrm{mm})(\mathrm{n}=3$ /group); cell viability - live/dead ( $\mathrm{n}=5$ /group); cell morphology (SEM) ( $\mathrm{n}=3$ /group); and gene expression (real-time PCR) ( $n=6 /$ group). Experiments were done in triplicate and repeated at least twice, according to ISO 10993-5 (2009) recommendations. ${ }^{28}$

\section{Materials}

n- $-\mathrm{TiO}_{2}$ (particle size $\square 20 \mathrm{~nm}$ and diameters $\square 10 \mathrm{~nm}$ ) was synthesized by the alkaline route. ${ }^{29}$ Briefly, $\mathrm{n}-\mathrm{TiO}_{2}$ was prepared by mixing $12 \mathrm{~g}$ of $\mathrm{TiO}_{2}$ anatase phase $99 \%$ purity with $200 \mathrm{~mL}$ of $10 \mathrm{M} \mathrm{NaOH}$. This mixture was kept at $120^{\circ} \mathrm{C}$ for $24 \mathrm{~h}$ in an open Teflon vessel, which was placed in a glycerin bath, using a mantle heater. The syntheses were carried out at ambient pressure, where only precursor reagents were subjected to alkaline treatment. After alkaline treatment, the mixture was washed with $0.1 \mathrm{M}$ hydrochloric acid and deionized water repeatedly to remove sodium ions. The $\mathrm{pH}$ of the solution was then adjusted to 7 . Finally, the materials obtained were dried in a conventional oven at $200^{\circ} \mathrm{C}$ for $24 \mathrm{~h} \cdot .^{14,29} \mathrm{~A}$ 
conventional GIC, Ketac Molar EasyMix ${ }^{\mathrm{TM}}$ [shade A3; powder: Al-Ca-La fluorosilicate glass, $5 \%$ copolymer acid (acrylic and maleic acids) (15 g); liquid: acrylic acid-maleic acid copolymer (25-40\% by weight), tartaric acid ( $5-10 \%$ by weight), and water ( $10 \mathrm{~g})]$ was used based on a previous review. ${ }^{4}$

\section{GIC sample preparation}

$\mathrm{n}-\mathrm{TiO}_{2}$ was weighed in a precision scale with $0.0001 \mathrm{~g}$ readability (Adventurer Ohaus, Parsippany, New Jersey, USA), added to the GIC's component powder and homogenized vigorously in a QL-901 vortex mixer (Biomixer, Taft, USA) for $2 \mathrm{~min} .{ }^{14,15}$ The recommended powder/liquid (P/L) ratio of $1 / 1$ for GIC was used for all prepared samples and manipulation was done following the manufacturer's specifications. GIC and GIC-n- $\mathrm{TiO}_{2}$ disks were prepared using Teflon bipartite disk molds in one increment and pressed for $6 \mathrm{~min}$ between the polyester matrix (Proben, Catanduva, Brazil, \#PR5021) and glass plates. They were covered with a thin layer of petroleum jelly (Rioquímica, São José do Rio Preto, SP, Brazil, \#1702146) and stored for $24 \mathrm{~h}$ at $37^{\circ} \mathrm{C}$ and $100 \%$ humidity. The disks were exposed to UV light for $15 \mathrm{~min}$ for each surface before the experiments. ${ }^{14}$

\section{Streptococcus mutans cultures}

S. mutans UA159 (ATCC 25175) strains were used in the present study. For each experiment, $300 \mu \mathrm{L}$ of the frozen stock were freshly cultured in $15-\mathrm{mL}$ Falcon tubes with $5 \mathrm{~mL}$ of brain-heart infusion (BHI) broth (DIFCO Laboratories, Detroit, MI, USA). The absorbance of 0.135 at $660 \mathrm{~nm}$ was achieved to obtain a concentration of $1 \times 10^{8}$ cells/mL (Genesys 2 spectrophotometer, Spectronic Unicam, Waltham, USA). ${ }^{30}$ The cultures were incubated for $24 \mathrm{~h}$ at $37^{\circ} \mathrm{C}$ in $10 \% \mathrm{CO}_{2}$ for the subsequent experiments.

\section{Agar diffusion test}

A base layer containing $15 \mathrm{~mL}$ of sterile BHI medium mixed with the inoculum was prepared for each Petri dish (15 x $90 \mathrm{~mm})$. After BHI agar solidification, six wells measuring $5 \mathrm{~mm}$ in diameter were prepared in each plate and filled with one of the experimental materials (GIC with or without $n-\mathrm{TiO}_{2}$ ). All materials were handled under aseptic conditions according to the manufacturer's instructions and inserted into the wells using a syringe (Centrix Inc., Shelton, USA). A thin layer of the agar was added to the wells, allowing total incorporation of the material in the culture medium. Chlorhexidine digluconate $0.12 \%$ solution and sterilized deionized water $(10 \mu \mathrm{L})$ were applied on sterile filter paper disks as positive and negative controls, respectively. The dishes were kept for $2 \mathrm{~h}$ at room temperature to allow the diffusion of the materials and were then incubated at $37^{\circ} \mathrm{C}$ and $10 \% \mathrm{CO}_{2}$. After 1, 3, and 7 days, inhibition zones around the materials were measured $(\mathrm{mm})$ using a digital caliper (Mitutoyo, MTI Corporation, Tokyo, Japan) by one calibrated evaluator (Spearman's correlation $=87 \%$ ).

\section{Cell viability test (live/dead)}

S. mutans strains were cultured on GIC disks ( $2 \mathrm{~mm}$ in height $\times 4 \mathrm{~mm}$ in diameter) in 24-well plates for 1,3 , and 7 days $\left(37^{\circ} \mathrm{C}\right.$ and $\left.10 \% \mathrm{CO}_{2}\right)$. The culture medium was then aspirated and the disks gently washed with saline solution. The plates were then maintained in a dark room and $25 \mu \mathrm{L}$ of a live/dead Baclight bacterial viability staining solution was used (Molecular Probes, Eugene, USA). The excitation/emission wavelengths of SYTO9 and propidium iodide were $480 / 500 \mathrm{~nm}$ and $490 / 635 \mathrm{~nm}$, respectively. Six images were captured under a fluorescence microscope (Zeiss, Jena, Germany) at 400X magnification from randomly selected sites for each analyzed surface. To determine the viability of the adhered bacterial species for each type of surface treatment, the green and red zones were separately determined, representing live and dead bacterial cells, respectively. The bacterial cell count for each dye in relation to the total area was performed on the ImageJ software (National Institute of Health, NIH, USA) and presented in arbitrary units (a.u.) and percentage for each surface. All images had a standard area of $97 \mu \mathrm{m}^{2}$, totaling $582 \mu \mathrm{m}^{2}$ for the six images analyzed. The experiments were carried out in triplicate for each surface. Positive and negative controls included bacteria cultured on glass coverslips and cultures treated with chlorhexidine digluconate $0.12 \%$ solution and plated on glass slides, respectively. 


\section{Scanning electron microscopy analysis (SEM)}

S. mutans strains were cultured on GIC and GIC-n- $\mathrm{TiO}_{2}$ disks $(2 \mathrm{~mm} \times 4 \mathrm{~mm})$ for 1,3 , and 7 days in 24-well plates in triplicate (Costar Corp, Cambridge, USA). After each experimental period, the cells were fixed in Karnovsky's solution (2.5\% glutaraldehyde and $2.0 \%$ paraformaldehyde in $0.1 \mathrm{M}$ phosphate buffer, $\mathrm{pH}$ 7.4) at room temperature for $2 \mathrm{~h}$. Subsequently, the samples were dehydrated in a graded series of ethanol and then stored in an oven at $37^{\circ} \mathrm{C}$ for overnight dehydration. ${ }^{14}$ They were then dried to a critical point (Denton Vacuum, mod. DCP-1, Moorestown, USA), coated with $10 \mathrm{~nm}$ of a gold layer on sputter coater (BAL-TEC, model SCD 050, Fürstentum, Liechtenstein) and kept in a desiccator until analysis. The structure and cell morphology of S. mutans colonies were assessed by a JEOL scanning electron microscope (JSM5600LV, Akishima, Tokyo, Japan) at 2000X magnification, $15 \mathrm{kV}$, and $10 \mathrm{~mm}$ of working distance.

\section{Gene expression analysis by real-time PCR}

S. mutans strains were cultured at $37^{\circ} \mathrm{C}$ and $10 \% \mathrm{CO}_{2}$ in $1.5 \mathrm{~mL}$ of $\mathrm{BHI}+1 \%$ sucrose on GIC disks $(2 \mathrm{~mm} \times 8 \mathrm{~mm})$ with or without the different concentrations of $\mathrm{n}-\mathrm{TiO}_{2}$ in 24-well plates for 24 and $72 \mathrm{~h}$. The culture medium was replaced every $24 \mathrm{~h}$ with fresh sterile $\mathrm{BHI}+1 \%$ sucrose. Gene expression assays were performed as previously described with some modifications. ${ }^{25}$ Briefly, 1 and 3 days after biofilm growth, the disks were removed from the culture medium and transferred to tubes containing $2 \mathrm{~mL}$ of saline solution $(0.9 \% \mathrm{NaCl})$. The samples were vortexed (2800 rpm/10 s) to promote cell detachment from the surface of disks, and the cell-containing solution was transferred to $2 \mathrm{~mL}$ microtubes (Axigen, New York, USA) and centrifuged ( 2 minutes, $4{ }^{\circ} \mathrm{C}, \approx 16000 \mathrm{~g}$ ) for cell pellet precipitation. Pellets were stored at $-80^{\circ} \mathrm{C}$ until use. Frozen cells were disrupted using $0.16 \mathrm{~g}$ of $0.1 \mathrm{~mm}$ diameter zirconia beads (Biospec, Bartlesville, USA), combined with $220 \mu \mathrm{L}$ of TE buffer on a MiniBeadbeater apparatus (Biospec), and total RNA was obtained using the RNeasy Mini Kit system as recommended by the manufacturer (Qiagen, Hilden, Germany). Next, $60 \mathrm{ng}$ of total RNA was converted to cDNA using iScript Reverse Transcriptase (Bio-Rad Laboratories, Hercules, CA, USA) following the recommended manufacturer's protocol. Real-time PCRs were performed on LightCycler 480 System (Roche Diagnostics $\mathrm{GmbH}$, Germany) using specific primers for vicR, $\operatorname{cov} R, g t f B, g t f C$, and $g t f D$ genes. ${ }^{27}$ Transcript levels were determined using the delta CT method (Table 1).

\section{Statistical analysis}

Data distribution and homoscedasticity were analyzed by the Shapiro-Wilk, Levene's, and Hartley's tests, respectively $(p \geq 0.05)$. Inhibition halo data were subjected to repeated-measures ANOVA followed by Tukey's test for multiple comparisons, whereas Dunn's test was used to assess statistical differences between the control and experimental groups individually. Besides, cell viability (viable, non-viable, and total bacteria) was transformed by Box-Cox and two-way ANOVA and Tukey's tests were performed. Gene expression data on $\operatorname{cov} R$, vicR and, gtfC were analyzed by two-way ANOVA followed by Tukey's test. $g t f B$ and $g t f D$ values presented non-homogeneous distribution and were subjected to the Kruskal-Wallis test. Statistical analyses were

Table 1. Primer sequences and product size information.

\begin{tabular}{lcc}
\hline Primers (qPCR) & Sequence 5'-3' & Product size \\
\cline { 2 - 3 } 16SRNA & CGGCAAGCTAATCTCTGAAA/GCCCCTAAAAGG TTACCTCA & 190 bp* \\
SMU.910 (gtfD) & TGATTCGTGGTATCGTCCTAA/GTTGAGACTTT CTTGGCTGCT & 199 bp* \\
SMU.1005 (gtfC) & ACCAACGCCACTGTTACT/AACGGTTACCGC TTTTGAT & 161 bp* \\
SMU.1004 (gtfB) & CGAATCCCAAATTCTAATGA/TGTTCCCCAACAGTATAAGGA & 197 bp* \\
SMU.1517 (vicR) & AGTGGCTGAGGAAAATGCTT/CATCACCTGACC TGTGTGTG & 163 bp* \\
SMU.1924 (covR) & ACGAAATATGGACGAACAC/CAGAGATGGACG GGTATGAA & 185 bp* \\
\hline
\end{tabular}

*Data obtained from Stipp et al., 2013.27 
performed using SPSS Statistics (version 21, IBM Statistics, New York, USA) and SAS System (ISAS Institute, Cary, USA), considering a significance level with $\alpha=0.05$.

\section{Results}

\section{Agar diffusion test}

Table 2 illustrates the findings for the agar diffusion test in $S$. mutans cultures. The between-group analysis showed that GIC with addition of $5 \% \mathrm{n}-\mathrm{TiO}_{2}$ had a superior antimicrobial activity $(\mathrm{p}<0.05)$ compared with $3 \%$ and $7 \% \mathrm{n}-\mathrm{TiO}_{2}$ groups but similar to that of the control group $(p>0.05)$ at all time points. Additionally, withingroup comparisons demonstrated no significant differences $(p>0.05)$ for antibacterial activity achieved at $24 \mathrm{~h}$ and at 3 and 7 days. Chlorhexidine, as the control of the method, presented the highest antibacterial capacity $(\mathrm{p}<0.05)$.

\section{Cell viability}

Figure 1 shows representative fluorescence microscopy images illustrating the live/dead assay for all groups and time points. Note the presence of more red cells for 3\% and 5\% concentrations for the initial time points, and higher counts of nonviable cells at 7 days for all groups, mostly GIC and $\mathrm{GIC}+3 \% \mathrm{n}-\mathrm{TiO}_{2}$. Figure 2 presents the total cell counts (\%/area) and the viable and non-viable cell numbers. There was a significant difference for the investigated factors: $\mathrm{n}-\mathrm{TiO}_{2}$ concentrations $(\mathrm{p}=0.0405)$; time of bacterial growth $(\mathrm{p}<0.001)$; and interaction between the two factors $(\mathrm{p}<0.001)$. The within-group analysis showed that $\mathrm{GIC}+7 \% \mathrm{n}-\mathrm{TiO}_{2}$ reduced the number of total bacterial counts over time with a significant difference at 7 days, whereas GIC $+3 \%$ $\mathrm{n}-\mathrm{TiO}_{2}$ displayed higher total bacterial counts at 7 days than at 3 days $(p<0.05)$. The number of viable cells was significantly lower for the control group at 7 days than at 1 and 3 days, and for $\mathrm{GIC}+7 \% \mathrm{n}-\mathrm{TiO}_{2}$, compared with day $1(\mathrm{p}<0.05)$.

The between-group analysis demonstrated an increased number of non-viable cells for all the experimental groups over time, with $\mathrm{GIC}+3 \% \mathrm{n}-\mathrm{TiO}_{2}$ and $\mathrm{GIC}+5 \% \mathrm{n}-\mathrm{TiO}_{2}$ displaying significant differences at day 7 ( $p<0.05)$. The total number of cells was significantly reduced for the $\mathrm{n}-\mathrm{TiO}_{2}$ groups at day 1 as compared with the control group, whereas this trend was maintained at days 3 and 7 for the 3\% and $7 \% \mathrm{n}-\mathrm{TiO}_{2}$ groups, respectively $(\mathrm{p}<0.05)$. The between-group analysis further revealed that the number of viable cells was significantly reduced for $\mathrm{GIC}+3 \% \mathrm{n}-\mathrm{TiO}_{2}$ and $\mathrm{GIC}+5 \% \mathrm{n}-\mathrm{TiO}_{2}$ at day 1 and $\mathrm{GIC}+3 \% \mathrm{n}-\mathrm{TiO}_{2}$ at day 3 , compared with the control group ( $\mathrm{p}<0.05)$, whereas the number of non-viable cells was not significantly affected $(p>0.05)$.

\section{Cell morphology by SEM}

Figure 3 illustrates SEM representative images for S. mutans cultured on GIC disks with addition or not of $\mathrm{n}-\mathrm{TiO}_{2}$ at 1,3 , and 7 days. SEM data showed that at $3 \%$ and $5 \%$, the presence of $n-\mathrm{TiO}_{2}$ affected cell morphology, resulting in a bacillary aspect with the cells organized in lines, whereas at $7 \%$ no visible cell morphology alteration could be noted.

Table 2. Agar diffusion test data illustrating the inhibition halo $(\mathrm{mm})$ (means $\pm \mathrm{SD}$ ) produced by each material, including GIC with and without different concentrations of $\mathrm{n}-\mathrm{TiO}_{2}$, in cultures of $\mathrm{S}$. mutans at 1,3 , and 7 days. Chlorhexidine $(\mathrm{CHX})$ at $0.12 \%$ was used as a positive control.

\begin{tabular}{lccc}
\hline Experimental groups & 1 day & 3 days & 7 days \\
\hline $\mathrm{GIC}$ (control) & $8.49(0.48) \mathrm{ABa}$ & $8.74(0.24) \mathrm{ABa}$ & $8.41(0.58) \mathrm{Aba}$ \\
$\mathrm{GIC}+3 \% \mathrm{n}-\mathrm{TiO}_{2}$ & $8.28(0.46) \mathrm{Ba}$ & $8.61(0.29) \mathrm{Ba}$ & $8.24(0.40) \mathrm{Ba}$ \\
$\mathrm{GIC}+5 \%{\mathrm{n}-\mathrm{TiO}_{2}}_{\mathrm{GIC}+7 \% \mathrm{n}^{-} \mathrm{TiO}_{2}}$ & $8.77(0.44) \mathrm{Aa}$ & $8.84(0.43) \mathrm{Aa}$ & $9.06(0.37) \mathrm{Aa}$ \\
$\mathrm{CHX}$ & $7.81(0.60) \mathrm{Ca}$ & $7.55(0.68) \mathrm{Ca}$ & $8.21(0.50) \mathrm{Ca}$ \\
$\mathrm{Gl}$ & $20.04(0.48)^{*}$ & $20.50(0.46)^{*}$ & $20.02(0.65)^{*}$ \\
\hline
\end{tabular}

GIC: Glass ionomer cement; $\mathrm{n}-\mathrm{TiO}_{2}$. Titanium dioxide nanotubes; $\mathrm{CHX}$ : Chlorhexidine $0.12 \%$.Different uppercase and lowercase letters represent between-group and within-group statistical differences, respectively, according to repeated-measures ANOVA followed by Dunn's test for additional comparisons $(p<0.05)$. *Indicates differences in Dunn's test considering chlorhexidine as the positive control $(p<0.05)$. 


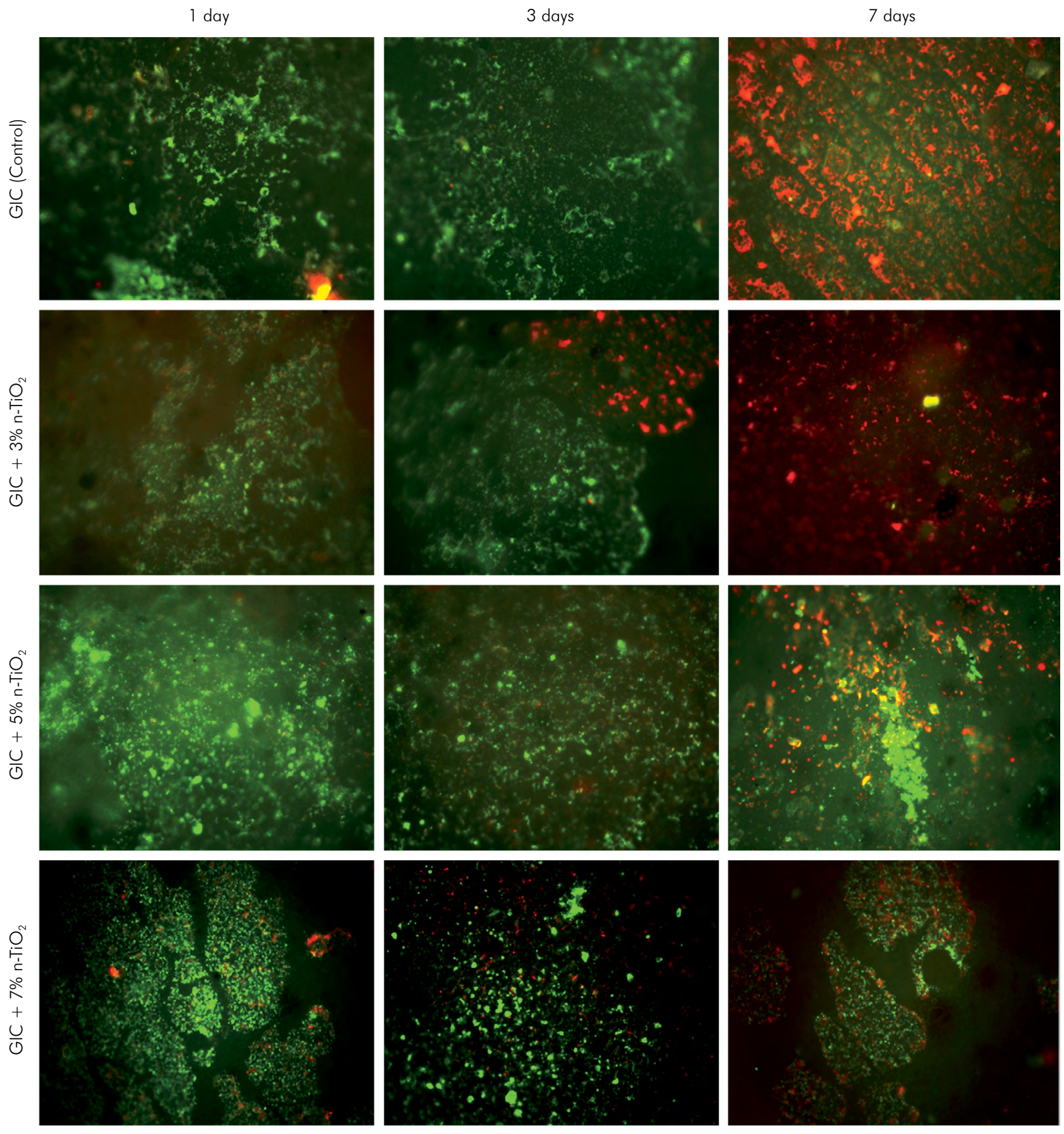

Figure 1. Fluorescence microscopy images representing the live (green) and dead (red) cells in contact with the materials at different time points. Fluorescence images are divided into rows (groups) and columns (time points).

\section{Gene expression analysis}

Overall, the data analysis showed that $\operatorname{cov} R$ was the most sensitive gene to the presence of $n-\mathrm{TiO}_{2}$ in the GIC matrix, whereas neither time nor $n-\mathrm{TiO}_{2}$ addition significantly affected transcript levels of vicR, $g t f B, g t f C$, and $g t f D$ in $S$. mutans cultures (Figure
4). At $24 \mathrm{~h}$, the presence of $\mathrm{n}-\mathrm{TiO}_{2}$ at $3 \%, 5 \%$, and $7 \%$ significantly reduced the expression of $\operatorname{cov} R$ as compared with GIC alone $(\mathrm{p}<0.05)$ with the lowest mRNA levels for the $3 \%$ group. Similar findings were observed at $72 \mathrm{~h}$, except for the fact that $\operatorname{cov} R$ mRNA levels were similar to those of GIC alone ( $p>0.05)$. In 


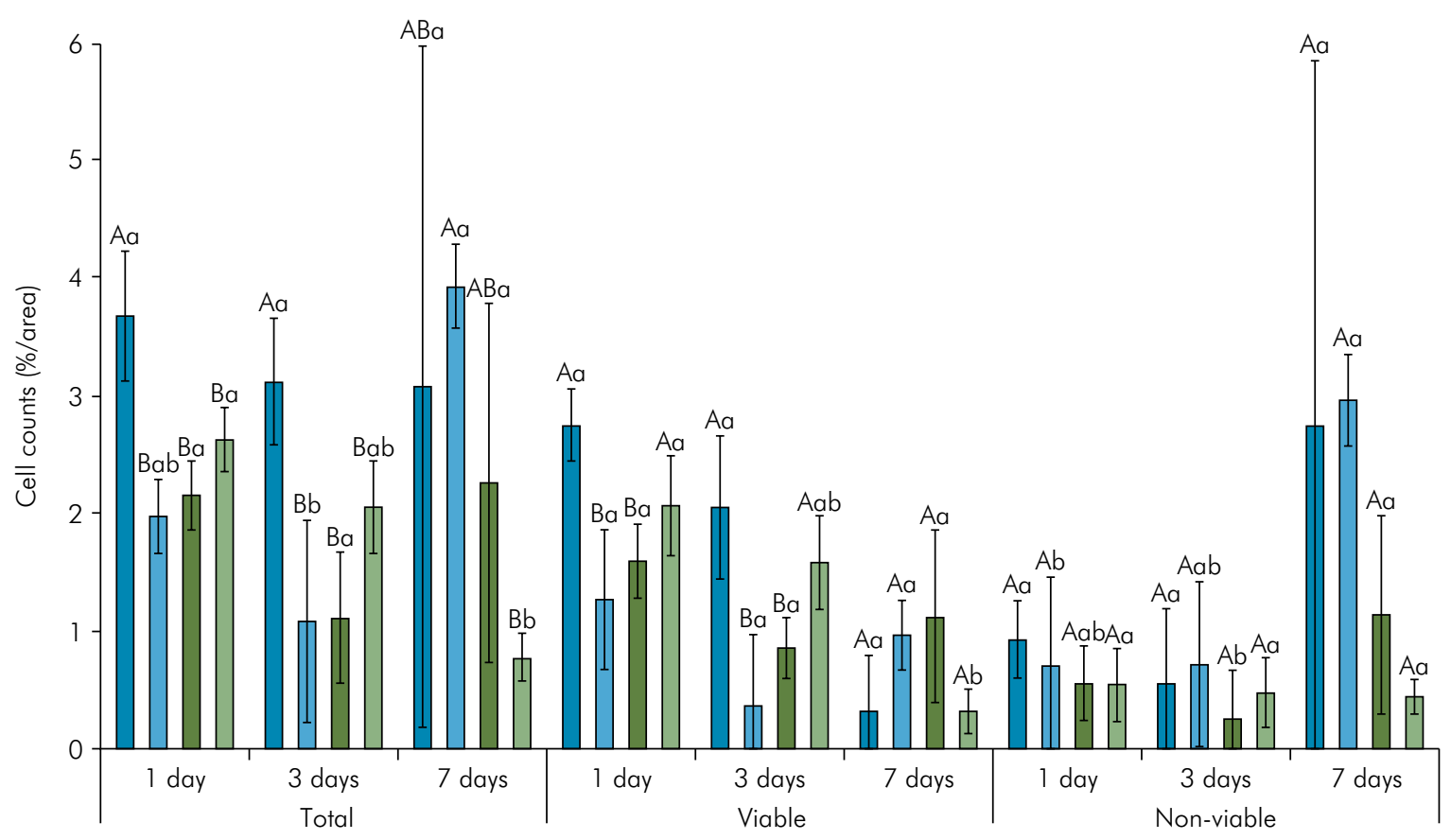

$\square \mathrm{GIC} \square \mathrm{GIC}+3 \% \mathrm{n}-\mathrm{TiO} 2 \quad \square \mathrm{GIC}+5 \% \mathrm{n}-\mathrm{TiO} 2 \quad \square \mathrm{GIC}+7 \% \mathrm{n}-\mathrm{TiO} 2$

Different uppercase and lowercase letters represent between-group and within-group statistical differences, respectively, according to two-way ANOVA ( $p<0.05$ ). Abbreviations: $\mathrm{GIC}$ : glass ionomer cement; $\mathrm{n}-\mathrm{TiO}_{2}$ : Titanium dioxide nanotubes.

Figure 2. Cell viability analysis (mean \pm SD) including total, viable, and non-viable bacterial counts (\%/area) at 1, 3, and 7 days.

addition, our findings demonstrated that, although not significant, vicR, $g t f C$, and $g t f D$ mRNA levels tended to decrease over time regardless of $n-\mathrm{TiO}_{2}$.

\section{Discussion}

In the current study, the data analysis showed that $\mathrm{n}-\mathrm{TiO}_{2}$ added to GIC potentially affected S. mutans properties. The presence of $\mathrm{n}-\mathrm{TiO}_{2}$ led to increased antibacterial activity, affected bacterial growth and morphology, and altered the expression of vicR. By contrast, it did not affect mRNA levels of $g t f B, g t f C$, and $g t f D$. Previous studies have suggested a potential antibacterial effect of $\mathrm{TiO}_{2}$ nanostructures added to conventional GIC. ${ }^{16,31,32}$ However, caution should be exercised when comparing different studies, as distinct methodologies may have been used.

In addition to the agar assay, the potential antibacterial properties of $\mathrm{n}-\mathrm{TiO}_{2}$ added to GIC were determined by assessing the impact of different concentrations of $\mathrm{n}-\mathrm{TiO}_{2}$ on the cell viability and morphology of $S$. mutans cultures. Our findings demonstrated that GIC+3\% $\mathrm{n}-\mathrm{TiO}_{2}$ and $\mathrm{GIC}+5 \% \mathrm{n}-\mathrm{TiO}_{2}$ reduced $\mathrm{S}$. mutans viability compared with the control group (GIC alone) and led to morphological alterations, including a rod-shaped structure rather than the typical spherical structure. These findings corroborate those of previous studies ${ }^{12,20}$ that reported antibacterial effects for $\mathrm{n}-\mathrm{TiO}_{2}$. While the mechanisms for a potential antibacterial effect of $\mathrm{n}-\mathrm{TiO}_{2}$ remain to be fully elucidated, it has been suggested that electrostatic interactions between metallic ions of nanostructured titanium and bacteria, ${ }^{33}$ attachment to the cell membrane, ${ }^{34}$ and the ensuing effects on phospholipids ${ }^{35}$ may explain some of the events controlling bacterial viability in the presence of $\mathrm{n}-\mathrm{TiO}_{2}$. Furthermore, it has been suggested that specific physicochemical properties of nanostructures may play a critical role in their functionality and use. ${ }^{20}$ In this sense, the antimicrobial effects of $n-\mathrm{TiO}_{2}$ evidenced here could be associated with nanometric size, shape, and the crystallinity of its structure. ${ }^{18-20}$ $\mathrm{TiO}_{2}$ nanotubes used in this study had $\sim 20 \mathrm{~nm}$ size 


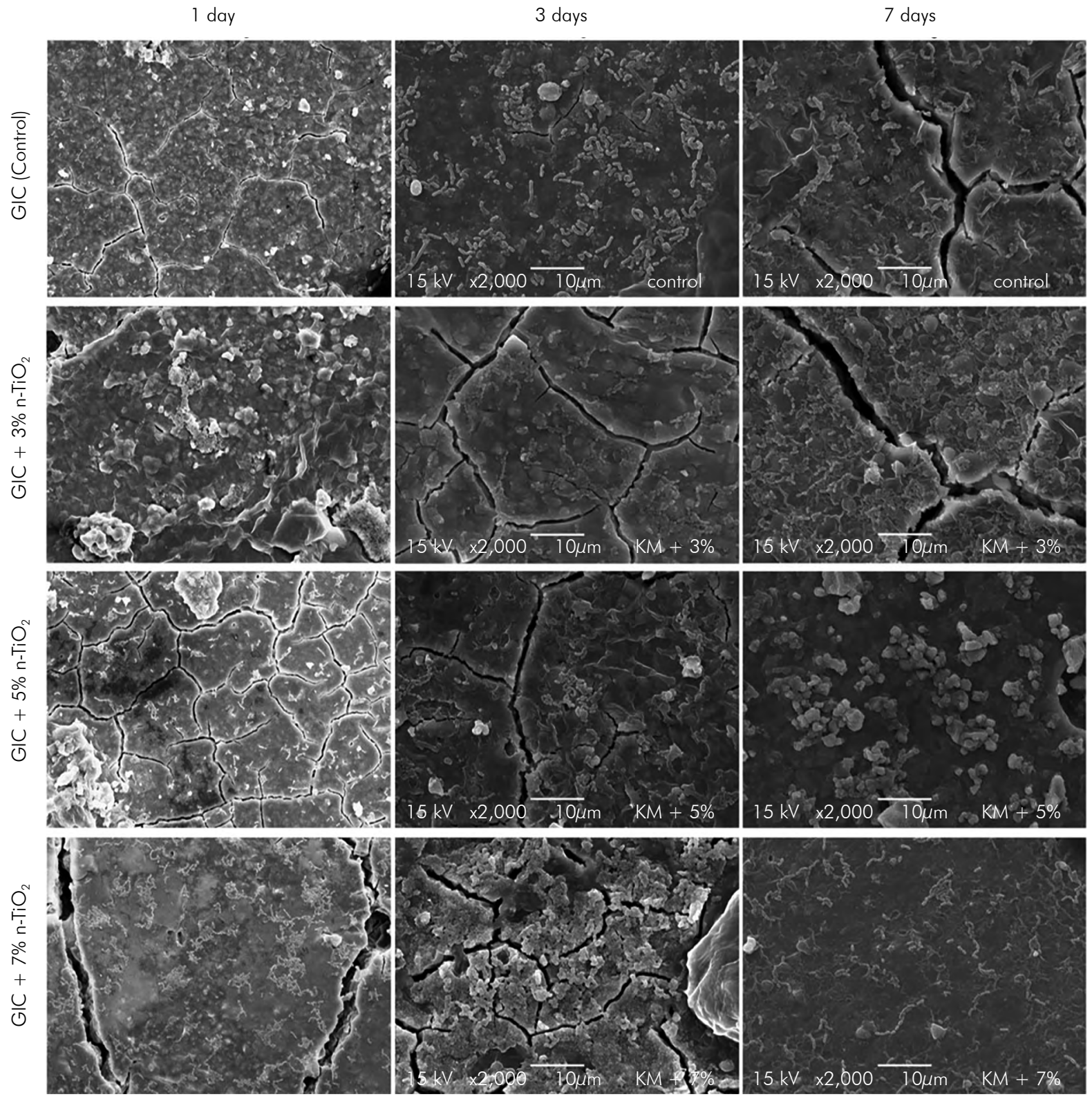

Figure 3. Scanning electron microscopy (SEM) of S. mutans cultures formed on GIC and n-TiO2 3\%, 5\%, and 7\% groups after 1, 3 , and 7 days (2000x magnification). SEM images are divided into rows (groups) and columns (time points).

and $\sim 10 \mathrm{~nm}$ diameter, which could facilitate their attachment to the cell membrane, inducing stress in the bacterial metabolism. This mechanism could be similar to that which occurs in other metallic nanoparticles. ${ }^{34}$ In addition, the anatase phase of $\mathrm{TiO}_{2}$ nanotubes used in this study reacts with water to form a hydroxyl radical by photocatalysis, interfering with membrane phospholipids ${ }^{34}$ and causing damage to the bacterial DNA. ${ }^{36}$ Besides the potential direct effect of $\mathrm{n}-\mathrm{TiO}_{2}$ on bacterial survival as discussed earlier, we hypothesized that changes in the chemical properties of conventional GIC promoted by $\mathrm{n}-\mathrm{TiO}_{2}$ may also influence its antibacterial capabilities. GIC alone has the potential to inhibit bacterial growth, ${ }^{37,38}$ which is mainly explained by fluoride release. ${ }^{2}$ Nonetheless, $\mathrm{n}-\mathrm{TiO}_{2}$ has the potential to boost fluoride release by conventional GIC, ${ }^{14}$ which does not exclude the hypothesis that higher fluoride levels in the biofilm microenvironment may also play a role in bacterial viability rates modulated by GIC. In the current study, 
gtfB expression

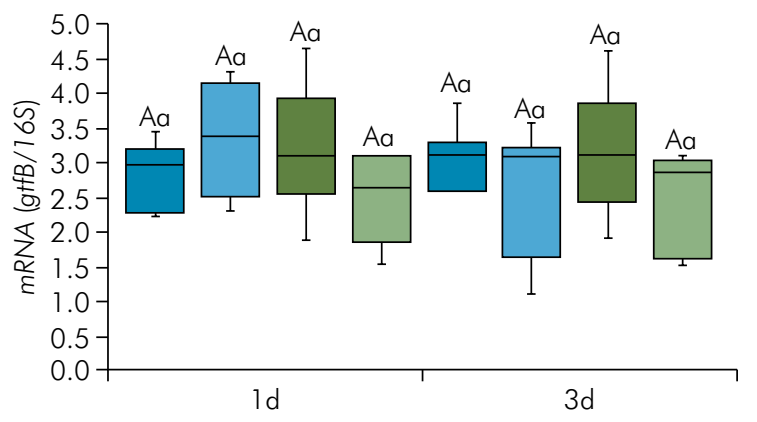

gtfD expression

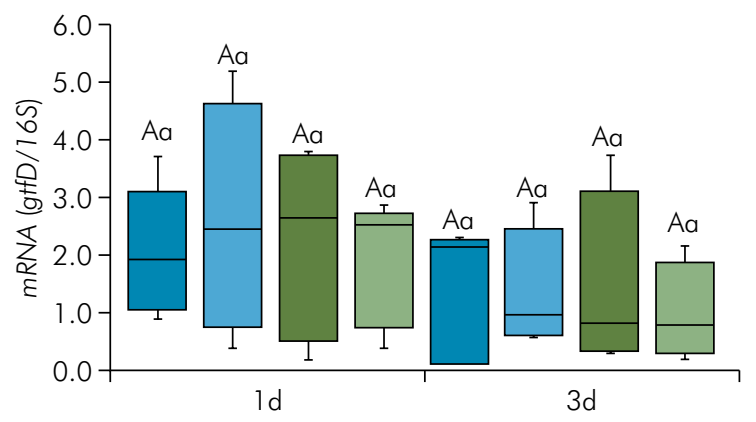

gHC expression

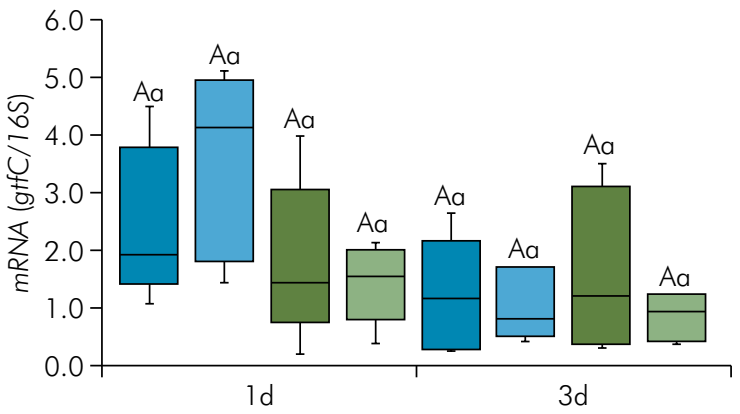

vicR expression

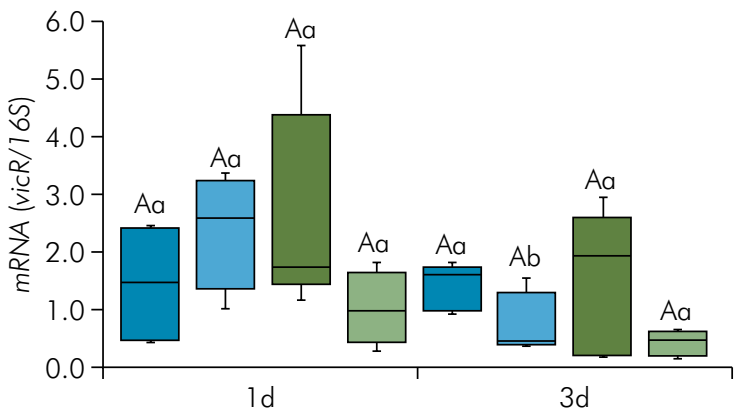

CovR expression

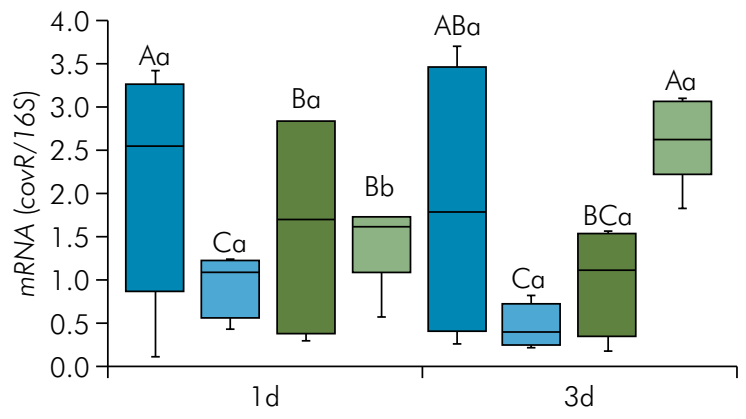

$\square \mathrm{GIC} \quad \square \mathrm{GIC}+3 \% \mathrm{n}-\mathrm{TiO} 2 \quad \square \mathrm{GIC}+5 \% \mathrm{n}-\mathrm{TiO} 2 \quad \square \mathrm{GIC}+7 \% \mathrm{n}-\mathrm{TiO} 2$

Different uppercase and lowercase letters represent between-group and within-group statistical differences, respectively, according to two-way ANOVA ( $p<0.05)$. Abbreviations: GIC: glass ionomer cement; $\mathrm{n}-\mathrm{TiO}_{2}$. Titanium dioxide nanotubes.

Figure 4. Bar graphs illustrating the relative expression of vicR, $\operatorname{cov} R, g f f B, g t f C$, and gtfD genes (median, maximum, and minimum values of $\mathrm{mRNA} / 16 \mathrm{~S}$ ) in $\mathrm{S}$. mutans cultures on experimental materials at 1 and 3 days.

gene expression was selected as the main variable of the study and it was used to calculate power and to determine sample size. Such an approach may have affected the statistical power of other variables including the number of cells and, therefore, these results must be interpreted with caution.

Moreover, we assessed whether $\mathrm{n}-\mathrm{TiO}_{2}$ added to conventional GIC would affect the expression of key genes controlling $S$. mutans virulence, including vicR, $\operatorname{cov} R, g t f B, g t f C$, and $g t f D$. Except for GIC $+7 \% \mathrm{n}-\mathrm{TiO}_{2}$ at $72 \mathrm{~h}, \mathrm{n}-\mathrm{TiO}_{2}$ incorporated into GIC significantly decreased the expression of $\operatorname{cov} R$, whereas vicR, gtfB, $g t f C$, and $g t f D$ were not affected. Once $\operatorname{cov} R$ has been shown to play a critical role in regulating several virulence factors that can affect $S$. mutans physiology, we evidenced that $\mathrm{GIC}+3 \% \mathrm{n}-\mathrm{TiO}_{2}$ and $\mathrm{GIC}+5 \%$ 
$\mathrm{n}-\mathrm{TiO}_{2}$ could interfere with biofilm formation, ${ }^{26,39}$ such as extracellular polysaccharide synthesis and interaction. ${ }^{26}$ To the authors' best knowledge, this is the first study that demonstrates an effect of $n-\mathrm{TiO}_{2}$ on the expression of a key gene for bacterial survival and biofilm formation. Therefore, this study adds new evidence to the potential mechanisms involved in $\mathrm{n}-\mathrm{TiO}_{2}$ antibacterial effect. Since $\operatorname{cov} \mathrm{R}$ has been shown to negatively regulate the expression of $g t f B$ and $g t f C$ genes by directly binding to their promoter regions, ${ }^{26}$ it could be expected that decreased levels of $\operatorname{cov} R$ would lead to increased expression of $g t f B$ and $g t f C$. By contrast, although $\mathrm{n}-\mathrm{TiO}_{2}$ at $3 \%$ and $5 \%$ increased mRNA levels for $g t f B$ and $g t f C$, no statistical significance could be found. Thus, the expression of vicR for these groups has possibly worked as a counterpart to balance the expression of the $g t f B C$ complex. This could be also assumed because cell viability for these groups was reduced and the cells were possibly trying to find mechanisms to preserve their viability. That assumption is also based on the expressions of $g t f B C$ at the $7 \%$ concentration, which were more similar to the expected down-regulatory effect of $\operatorname{cov} R$, and on its number of viable and nonviable cells at 1 and 3 days. Together, these findings provide new insights into the potential mechanisms by which $\mathrm{n}-\mathrm{TiO}_{2}$ may affect bacterial metabolism in vivo, but future studies should be designed to determine the mechanisms by which $\mathrm{TiO}_{2}$ affects the expression of key regulatory gene in $S$. mutans. Apart from that, it seems that $\mathrm{GIC}+3 \% \mathrm{n}-\mathrm{TiO}_{2}$ has a progressive effect on $\mathrm{S}$. mutans during the first $72 \mathrm{~h}$, once vicR expression was lower at $72 \mathrm{~h}$ than at $24 \mathrm{~h}$ in the within-group comparison. Down-regulatory effects on vicR could affect cell membrane homeostasis since this gene is related to its biosynthesis, ${ }^{40}$ corroborating the cell morphology modifications evidenced by SEM images. Importantly, a previous study has demonstrated that n- $-\mathrm{TiO}_{2}$ added to GIC had a positive impact on human cells (fibroblasts) and on cell morphology/spreading and ECM composition. ${ }^{14}$

Therefore, the present study demonstrates that the addition of $\mathrm{n}-\mathrm{TiO}_{2}$ to conventional GIC interfered with $S$. mutans metabolism, modulating the expression of key regulatory genes, affecting cell morphology and decreasing the number of viable cells. Although the use of nanotechnology has risen as a promising approach to modulate bacterial biofilms in vivo, at this time, the reported results refer to an in vitro monoculture system with no quantification of extracellular polysaccharides. Hence, future studies should be performed to determine whether $\mathrm{n}-\mathrm{TiO}_{2}$ also affects glucan synthesis and the matrix organization and to assess the effects of these materials on more complex multispecies biofilms in vivo.

\section{Conclusion}

The use of GIC added to $n-\mathrm{TiO}_{2}$ at $3 \%$ and $5 \%$ can potentially affect bacterial biofilm formation by reducing cell viability and affecting the expression of key genes for bacterial survival and growth, improving the anticariogenic properties of GICs.

\section{Acknowledgments}

The authors thank the staff at the Microbiology and Molecular Biology of Faculdade São Leopoldo Mandic, Campinas, SP, Brazil; Ms. Gilca Sabba, Mr. Thiago Santos, Ms. Pollyana Tombini Montaldi, and Ms. Fabiana Cesário Vieira for their technical assistance. The authors also thank the financial support from São Paulo Research Support Foundation (FAPESP, Grant \# 16/13786-0 \& Grant \# 19/14078-8) and the Brazilian National Council for Scientific and Technological Development (CNPq -Scholarship PIBIC 2018-2019). The authors declare there are no conflicts of interest related to this research.

\section{References}

1. Anusavice KJ, Shen C, Rawls HR. Phillips' science of dental materials. 12th ed. Saint Louis: Elsevier Sounders; 2013.

2. Nakajo K, Imazato S, Takahashi Y, Kiba W, Ebisu S, Takahashi N. Fluoride released from glass-ionomer cement is responsible to inhibit the acid production of caries-related oral streptococci. Dent Mater. 2009 Jun;25(6):703-8. https://doi.org/10.1016/i.dental.2008.10.014 
Araújo IJS, Ricardo MG, Gomes OP, Giovani PA, Puppin-Rontani J, Pecorari VA, Martinez EF, et al.

3. Xie D, Brantley WA, Culbertson BM, Wang G. Mechanical properties and microstructures of glass-ionomer cements. Dent Mater. 2000 Mar;16(2):129-38. https://doi.org/10.1016/S0109-5641(99)00093-7

4. Amorim RG, Frencken JE, Raggio DP, Chen X, Hu X, Leal SC. Survival percentages of atraumatic restorative treatment (ART) restorations and sealants in posterior teeth: an updated systematic review and meta-analysis. Clin Oral Investig. 2018 Nov;22(8):2703-25. https://doi.org/10.1007/s00784-018-2625-5

5. Mazzaoui SA, Burrow MF, Tyas MJ. Fluoride release from glass ionomer cements and resin composites coated with a dentin adhesive Dent Mat. 2000 May;16(3):166-71. https://doi.org/10.1016/S0109-5641(00)00003-8

6. Kantovitz KR, Pascon FM, Correr GM, Alonso RC, Rodrigues LK, Alves MC, et al. Influence of environmental conditions on properties of ionomeric and resin sealant materials. J Appl Oral Sci. 2009 Jul-Aug;17(4):294-300. https://doi.org/10.1590/S1678-77572009000400006

7. Basso GR, Della Bona A, Gobbi DL, Cecchetti D. Fluoride release from restorative materials. Braz Dent J. 2011;22(5):355-8. https://doi.org/10.1590/S0103-64402011000500001

8. Croll TP, Nicholson JW. Glass ionomer cements in pediatric dentistry: review of the literature. Pediatr Dent. 2002 Sep-Oct;24(5):423-9.

9. Kampanas NS, Antoniadou M. Glass ionomer cements for the restoration of non-carious cervical lesions in the geriatric patient. J Funct Biomater. 2018 Jul;9(3):42. https://doi.org/10.3390/jfb9030042

10. Medeiros FC, Santos MM, Araújo IJ, Lima IP. Clinical evaluation of two materials in the restoration of abfraction lesions. Braz J Oral Sci. 2015;14(4):287-93. https://doi.org/10.1590/1677-3225v14n4a07

11. Khademolhosseini M, Barounian M, Eskandari A, Aminzare M, Zahedi A, Grahremani D. Development of new Al2O3/TiO2 reinforced glass-ionomer cements (GICs). J Basic Appl Sci Res. 2012;2(8):7526-9.

12. Sun J, Xu Y, Zhu B, Gao G, Ren J, Wang H, et al. Synergistic effects of titanium dioxide and cellulose on the properties of glass-ionomer cement Dent Mat J. 2019;38:41-51. https://doi.org/10.4012/dmj.2018-001

13. Ibrahim MA, Meera Priyadarshini B, Neo J, Fawzy AS. Characterization of Chitosan/TiO 2 nano-powder modified glass-ionomer cement for restorative dental applications. J Esthet Restor Dent. 2017 Apr;29(2):146-56. https://doi.org/10.1111/jerd.12282

14. Cibim DD, Saito MT, Giovani PA, Borges AF, Pecorari VG, Gomes OP, et al. Novel nanotechnology of TiO 2 improves physical-chemical and biological properties of glass ionomer cement. Int J Biomater. 2017;2017:7123919. https://doi.org/10.1155/2017/7123919

15. Kantovitz KR, Fernandes FP, Feitosa IV, Lazzarini MO, Denucci GC, Gomes OP, et al. TiO2 nanotubes improve physico-mechanical properties of glass ionomer cement. Dent Mater. 2020 Mar;36(3):e85-92. https://doi.org/10.1016/i.dental.2020.01.018

16. Elsaka SE, Hamouda IM, Swain MV. Titanium dioxide nanoparticles addition to a conventional glass-ionomer restorative: influence on physical and antibacterial properties. J Dent. 2011 Sep;39(9):589-98. https://doi.org/10.1016/i.jdent.2011.05.006

17. Hamid N, Telgi RL, Tirth A, Tandon V, Chandra S, Chaturvedi RK. Titanium Dioxide nanoparticles and cetylpyridinium chloride enriched glass-ionomer restorative cement: a comparative study assessing compressive strength and antibacterial activity. J Clin Pediatr Dent. 2019;43(1):42-5. https://doi.org/10.17796/1053-4625-43.1.8

18. Ercan B, Taylor E, Alpaslan E, Webster TJ. Diameter of titanium nanotubes influences anti-bacterial efficacy. Nanotechnology. 2011 Jul;22(29):295102. https://doi.org/10.1088/0957-4484/22/29/295102

19. Ashkarran A, Hamidinezhad H, Haddadi H, Mahmoudi M. Applied surface science double-doped TiO 2 nanoparticles as an efficient visible-light-active photocatalyst and antibacterial agent under solar simulated light. Appl Surf Sci. 2014;301:338-45. https://doi.org/10.1016/i.apsusc.2014.02.074

20. Vimbela GV, Ngo SM, Fraze C, Yang L, Stout DA. Antibacterial properties and toxicity from metallic nanomaterials. Int J Nanomedicine. 2017 May;12:3941-65. https://doi.org/10.2147/IJN.S134526

21. Gjorgievska E, Van Tendeloo G, Nicholson JW, Coleman NJ, Slipper IJ, Booth S. The incorporation of nanoparticles into conventional glass-ionomer dental restorative cements. Microsc Microanal. 2015 Apr;21(2):392-406. https://doi.org/10.1017/S1431927615000057

22. Dias HB, Bernardi MI, Bauab TM, Hernandes AC, Rastelli ANS. Titanium dioxide and modified titanium dioxide by silver nanoparticles as an anti biofilm filler content for composite resins. Dent Mater. 2019 Feb;35(2):e36-46. https://doi.org/10.1016/i.dental.2018.11.002

23. Zhang JF, Wu R, Fan Y, Liao S, Wang Y, Wen ZT, et al. Antibacterial dental composites with chlorhexidine and mesoporous silica. J Dent Res. 2014 Dec;93(12):1283-9. https://doi.org/10.1177/0022034514555143

24. Cheng L, Weir MD, Zhang K, Wu EJ, Xu SM, Zhou X, et al. Dental plaque microcosm biofilm behavior on calcium phosphate nanocomposite with quaternary ammonium. Dent Mater. 2012 Aug;28(8):853-62. https://doi.org/10.1016/j.dental.2012.04.024

25. Araújo IJS, Paula AB, Alonso RCB, Taparelli JR, Mei LHI, Stipp RN, et al. A novel triclosan methacrylate-based composite reduces the virulence of Streptococcus mutans biofilm. PLoS One 2018;13(4):e0195244. https://doi.org/10.1371/journal. pone.0195244.

26. Biswas S, Biswas I. Regulation of the glucosyltransferase (gtfBC) operon by CovR in Streptococcus mutans. J Bacteriol. 2006 Feb;188(3):988-98. https://doi.org/10.1128/JB.188.3.988-998.2006

27. Stipp RN, Boisvert H, Smith DJ, Höfling JF, Duncan MJ, Mattos-Graner RO. CovR and VicRK regulate cell surface biogenesis genes required for biofilm formation in Streptococcus mutans. PLoS One. 2013;8(3):e58271. https://doi.org/10.1371/journal.pone.0058271

28. International Organization for Standardization - ISO. ISO 10993-5:2009 - Biological evaluation of medical devices. Geneva: International Organization for Standardization ; 2009. 
Titanium dioxide nanotubes added to glass ionomer cements affect S. mutans viability and mechanisms of virulence

29. Arruda LB, Santos CM, Orlandi MO, Schreiner WH, Lisboa-filho PN. Formation and evolution of TiO 2 nanotubes in alkaline synthesis. Ceram Int. 2015;41(2):2884-91. https://doi.org/10.1016/i.ceramint.2014.10.113

30. Kim S, Song M, Roh BD, Park SH, Park JW. Inhibition of Streptococcus mutans biofilm formation on composite resins containing ursolic acid. Restor Dent Endod. 2013 May;38(2):65-72. https://doi.org/10.5395/rde.2013.38.2.65

31. Garcia-Contreras R, Scougall-Vilchis RJ, Contreras-Bulnes R, Sakagami H, Morales-Luckie RA, Nakajima H. Mechanical, antibacterial and bond strength properties of nano-titanium-enriched glass ionomer cement. J Appl Oral Sci. 2015 May-Jun;23(3):321-8. https://doi.org/10.1590/1678-775720140496

32. Vermeersch G, Leloup G, Delmée M, Vreven J. Antibacterial activity of glass-ionomer cements, compomers and resin composites: relationship between acidity and material setting phase. J Oral Rehabil. 2005 May;32(5):368-74. https://doi.org/10.1111/i.1365-2842.2004.01300.x

33. Tavassoli Hojati S, Alaghemand H, Hamze F, Ahmadian Babaki F, Rajab-Nia R, Rezvani MB, et al. Antibacterial, physical and mechanical properties of flowable resin composites containing zinc oxide nanoparticles. Dent Mater. 2013 May;29(5):495-505. https://doi.org/10.1016/i.dental.2013.03.011

34. Zhou Y, Kong Y, Kundu S, Cirillo JD, Liang H. Antibacterial activities of gold and silver nanoparticles against Escherichia coli and bacillus Calmette-Guérin. J Nanobiotechnology. 2012 May;10(1):19. https://doi.org/10.1186/1477-3155-10-19

35. Wong MS, Chu WC, Sun DS, Huang HS, Chen JH, Tsai PJ, et al. Visible-light-induced bactericidal activity of a nitrogen-doped titanium photocatalyst against human pathogens. Appl Environ Microbiol. 2006 Sep;72(9):6111-6. https://doi.org/10.1128/AEM.02580-05

36. Hirakawa K, Mori M, Yoshida M, Oikawa S, Kawanishi S. Photo-irradiated titanium dioxide catalyzes site specific DNA damage via generation of hydrogen peroxide. Free Radic Res. 2004 May;38(5):439-47. https://doi.org/10.1080/1071576042000206487

37. Chau NP, Pandit S, Cai JN, Lee MH, Jeon JG. Relationship between fluoride release rate and anti-cariogenic biofilm activity of glass ionomer cements. Dent Mater. 2015 Apr;31(4):e100-8. https://doi.org/10.1016/i.dental.2014.12.016

38. Hayacibara MF, Rosa OP, Koo H, Torres SA, Costa B, Cury JA. Effects of fluoride and aluminum from ionomeric materials on S. mutans biofilm. J Dent Res. 2003 Apr;82(4):267-71. https://doi.org/10.1177/154405910308200405

39. Chong P, Drake L, Biswas I. Modulation of covR expression in Streptococcus mutans UA159. J Bacteriol. 2008 Jul;190(13):4478-88. https://doi.org/10.1128/JB.01961-07

40. Senadheera MD, Guggenheim B, Spatafora GA, Huang YCC, Choi J, Hung DCl, et al. A VicRK signal transduction system in Streptococcus mutans affects gtfBCD, gbpB, and ftf expression, biofilm formation, and genetic competence development. J Bacteriol. 2005 Jun;187(12):4064-76. https://doi.org/10.1128/JB.187.12.4064-4076.2005 